\title{
Erratum to: Quantification of Dendritic Austenite After Interrupted Solidification in Hypoeutectic Lamellar Graphite Iron
}

\author{
Björn Domeij $^{1}$ (1) $\cdot$ Juan Carlos Hernando ${ }^{1} \cdot$ Attila Diószegi $^{1}$
}

Published online: 19 May 2017

(C) Springer Science+Business Media New York and ASM International 2017

Erratum to: Metallogr. Microstruct. Anal. (2016)

\section{5:28-42}

DOI: $10.1007 / \mathrm{s} 13632-015-0250-0$

In this article, there was an error in the composition of the materials listed in Table 1, as the composition was mixed up with a related material. The correct composition is found in the table below (Table 1).

In experiments of equivalent conditions, we have found that the ledeburite matrix is slightly coarser for high contents of Mo. The difference is in no way devastating, because we have performed measurements on the material of the erroneous composition using the method described in the paper without great difficulty. However, the discussion of sources of error and disagreement with the point fraction and line intercept method may have been different if the article concerned a material using the erroneous composition.

Table 1 Chemical composition of material

\begin{tabular}{lllllllllll}
\hline $\mathrm{CE}$ & $\mathrm{C}$ & $\mathrm{Si}$ & $\mathrm{Mn}$ & $\mathrm{S}$ & $\mathrm{P}$ & $\mathrm{Cu}$ & $\mathrm{Sn}$ & $\mathrm{Mo}$ & $\mathrm{Cr}$ & $\mathrm{Fe}$ \\
\hline 4.05 & 3.4 & 1.89 & 0.57 & 0.09 & 0.05 & 0.9 & 0.05 & 0.05 & 0.15 & $\mathrm{Bal}$.
\end{tabular}

The online version of the original article can be found under doi: 10.1007/s13632-015-0250-0.

\footnotetext{
Björn Domeij

bjorn.domeij@ju.se

1 Department of Materials and Manufacturing, Jönköping University, 55111 Jönköping, Sweden
} 